\title{
PENGARUH KEDISIPLINAN DAN KEMANDIRIAN BELAJAR TERHADAP HASIL BELAJAR EKONOMI MADRASAH ALIYAH DI KECAMATAN PRAYA
}

\author{
Muhammad Sobri, Moerdiyanto \\ MTs darul Ittihad Gerepek Lombok Tengah, Universitas Negeri Yogyakarta \\ sobripraya@gmail.com,murdiyanto_351@yahoo.com
}

\begin{abstract}
Abstrak
Penelitian ini bertujuan mengetahui pengaruh kedisiplinan dan kemandirian belajar terhadap hasil belajar ekonomi siswa kelas XI jurusan IPS Madrasah Aliyah di Kecamatan Praya. Desain penelitian ini adalah expostfacto dengan jenis penelitian assosiatif. Data yang diperoleh dianalisis dengan teknik analisis deskriptif dan regresi linier ganda. Hasil penelitian Madrasah Aliyah di Kecamatan Praya menunjukkan bahwa: (1) ketuntasan belajar siswa sebesar 90,05\%; (2) kedisiplinan belajar siswa tergolong rendah dengan rata-rata 44,39; (3) kemandirian belajar siswa tergolong rendah dengan rata-rata 55,23; (4) kedisiplinan belajar berpengaruh positif terhadap hasil belajar ekonomi siswa (thitung $=5,22 ; \alpha=0,00$ ), dengan koefisien determinasi sebesar 28,1\%; (5) kemandirian belajar berpengaruh positif terhadap hasil belajar ekonomi siswa (thitung $=2,36 ; \alpha=0,02$ ), dengan koefisien determinasi sebesar $21,2 \%$; dan (6) kedisiplinan dan kemandirian belajar secara bersamaan berpengaruh positif terhadap hasil belajar siswa (Fhitung=47,21; $\alpha=0,00$ ), dengan koefisien determinasi sebesar $29,6 \%$.
\end{abstract}

Kata Kunci: Kedisiplinan Belajar, Kemandirian Belajar, dan Hasil Belajar

\section{THE EFFECT OF DISCIPLINE AND AUTONOMY LEARNING ON THE LEARNING ACHIEVEMENT IN ECONOMICS SUBJECT}

\author{
Muhammad Sobri, Moerdiyanto \\ MTs darul Ittihad Gerepek Lombok Tengah, Universitas Negeri Yogyakarta \\ sobripraya@gmail.com,murdiyanto_351@yahoo.com
}

\begin{abstract}
This research aimed to investigate the effect of discipline and autonomy learning on the learning achievement in economics subject of class XI student of social studies major Madrasah Aliyah in Praya subdistrict. This research was an expost facto design with associative approach. The data were analyzed by the descriptive analysis and linear multiple regression. The results show that: (1) completeness learning of student which is $90.05 \%$; (2) discipline learning of students are low with mean is 44.39; (3) autonomy learning of students are low with mean is 55.23; (4) discipline learning positively influences the learning achievement in economics subject of students $\left(t_{\text {count }}=5.22 ; \alpha=0.00\right)$, with coefficient determination which is $28.1 \%$; (5) autonomy learning positively influences the learning achievement in economics subject of students $\left(t_{\text {count }}=2.361 ; \alpha=0.02\right)$, with coefficient determination which is $21,2 \%$; and (6) discipline and autonomy learning positively influence the learning achievement in economics subject of students $\left(F_{\text {count }}=47.21 ; \alpha=0.00\right)$, with coefficient determination is $29.6 \%$.
\end{abstract}

Keyword: Discipline Learning, Autonomy Learning, and Learning Achievement 


\section{Pendahuluan}

Pendidikan merupakan kebutuhan manusia untuk meningkatkan kemampuan dan mengembangkan potensinya yang berlangsung sepanjang hayat. Pendidikan bertujuan untuk membentuk sumber daya manusia yang berkualitas sehingga mampu dan proaktif menjawab tantangan zaman yang selalu berubah.

Pada Undang-Undang Nomor 20 Tahun 2003 tentang Sistem Pendidikan Nasional pasal 3 bahwa pendidikan dimaknai sebagai:

...usaha sadar dan terencana untuk mewujudkan suasana belajar dan proses pembelajaran agar peserta didik secara aktif mengembangkan potensi dirinya untuk memiliki kekuatan spiritual keagamaan, pengendalian diri, kepribadian, kecerdasan, akhlak mulia, serta keterampilan yang diperlukan dirinya, masyarakat, bangsa dan negara (Depdiknas, 2003).

Pendidikan dilaksanakan secara terencana dan sistematis agar tujuan pendidikan dapat tercapai sesuai dengan harapan melalui kegiatan pembelajaran yang efektif dan efisien. Kegiatan pembelajaran terdiri atas perencanaan, pelaksanaan dan penilaian. Perencanaan mencakup pembuatan silabus dan rencana pelaksanaan pembelajaran (RPP). Melalui perencanaan diharapkan kegiatan pembelajaran menjadi terarah sesuai dengan tujuan yang ditentukan. Pelaksanaan pembelajaran meliputi kegiatan penyampaian materi dengan menggunakan strategi dan atau metode tertentu supaya pembelajaran berjalan efektif. Penilaian dalam kegiatan pembelajaran dilakukan untuk memantau seberapa efektif metode pembelajaran yang digunakan. Penilaian juga berguna untuk melihat kemampuan atau hasil belajar siswa setelah mengikuti proses pembelajaran

Berkaitan dengan hasil belajar, Suryabrata (2002, p. 233) menjelaskan bahwa hasil belajar siswa dipengaruhi oleh faktor eksternal dan faktor internal. Faktor eksternal adalah faktor yang datang dari luar diri siswa yang meliputi lingkungan sosial dan nonsosial. Sedangkan faktor internal adalah faktor yang berasal dari keadaan diri siswa, meliputi jasmani dan rohani/kepribadian termasuk dalam hal ini adalah kedisiplinan dan kemandirian belajar siswa.
Ekonomi merupakan salah mata pelajaran dalam kurikulum tingkat satuan pendidikan (KTSP). Ekonomi diberikan pada jenjang Sekolah Menengah Atas dan Madrasah Aliyah melalui pendekatan terpisah, tidak terpadu. Dalam lampiran Peraturan Menteri Pendidikan Nasional Nomor 22 Tahun 2006 Tentang Standar Isi untuk Satuan Pendidikan Dasar dan Menengah menyebutkan bahwa Ekonomi pada jenjang pendidikan Sekolah Menengah Atas dan Madrasah Aliyah bertujuan agar siswa memiliki kemampuan sebagai berikut: (1) Memahami sejumlah konsep ekonomi untuk mengkaitkan peristiwa dan masalah ekonomi dengan kehidupan sehari-hari, terutama yang terjadi dilingkungan individu, rumah tangga, masyarakat, dan negara; (2) Menampilkan sikap ingin tahu terhadap sejumlah konsep ekonomi yang diperlukan untuk mendalami ilmu ekonomi; (3) Membentuk sikap bijak, rasional dan bertanggungjawab dengan memiliki pengetahuan dan keterampilan ilmu ekonomi, manajemen, dan akuntansi yang bermanfaat bagi diri sendiri, rumah tangga, masyarakat, dan negara; (4) Membuat keputusan yang bertanggungjawab mengenai nilai-nilai sosial ekonomi dalam masyarakat yang majemuk, baik dalam skala nasional maupun internasional (Depdiknas, 2006).

Dengan kemampuan tersebut, siswa dapat menyelesaikan masalah-masalah berkaitan dengan sosial ekonomi yang dihadapi dalam kehidupan bermasyarakat secara rasional dan bertanggung jawab serta mengambil keputusan dengan mempertimbangkan nilai-nilai positif dalam masyarakat yang majemuk.

Kemampuan siswa dalam mata pelajaran Ekonomi dapat diwujudkan melalui proses pembelajaran yang memberikan kebebasan pada siswa untuk mengekspresikan dan menyampaikan pendapatnya; pembelajaran yang memperhatikan karakteristik siswa sehingga hasil belajar yang diharapkan dapat tercapai. Realitas di lapangan menunjukkan bahwa hasil belajar siswa pada pelajaran Ekonomi masih kurang memuaskan.

Berdasarkan hasil Ujian Nasional tahun 2010, nilai rata-rata pada mata pelajaran Ekonomi sebesar 6,57 dengan nilai terendah 1,50 dan tertinggi 9,50 (Depdiknas, 2010). Hal tersebut memberikan petunjuk bahwa nilai siswa pada mata pelajaran Ekonomi tergolong rendah. 
Nilai rata-rata siswa pada pelajaran ekonomi dalam ujian nasional Madrasah Aliyah di Kecamatan Praya lebih rendah dibandingkan dengan daerah lain yang ada di Kabupaten Lombok Tengah seperti di Kecamatan Pujut dan Praya Barat.

Data hasil ujian nasional tahun menunjukkan bahwa nilai rata-rata siswa pada mata pelajaran ekonomi Madrasah Aliyah di Kecamatan Pujut sebesar 6,67 dan di Kecamatan Praya Barat sebesar 6,98 (Depdiknas, 2010). Hal ini menunjukkan bahwa nilai rata-rata siswa pada pelajaran ekonomi Madrasah Aliyah di Kecamatan Pujut dan Praya Barat lebih tinggi dibanding dengan Madrasah Aliyah yang ada di Kecamatan Praya.

Salah satu penyebab rendahnya hasil belajar pada mata pelajaran Ekonomi adalah proses pembelajaran belum efektif. Proses pembelajaran masih terlalu berorientasi terhadap penguasaan teori dan hafalan yang menyebabkan kemampuan belajar siswa menjadi terhambat. Selain itu, metode pembelajaran terlalu berorientasi pada guru (teacher oriented) yang mengabaikan hakhak dan perkembangan siswa sehingga proses pembelajaran menjadi kurang optimal.

Berdasarkan hasil observasi awal pada salah satu Madrasah Aliyah di Kecamatan Praya pada tanggal 27 Mei 2013, ditemukan masalah terkait dengan rendahnya hasil belajar siswa. Selain itu, siswa memiliki kedisiplinan yang rendah. Hal tersebut diindikasikan dengan perilaku siswa yang menyelesaikan pekerjaan rumah (PR) di sekolah; tidak memakai seragam sekolah sesuai dengan waktu yang ditentukan pihak sekolah; adanya siswa terlambat datang sekolah yang mengganggu konsentrasi belajar; dan adanya siswa yang telat mengumpulkan tugas yang diberikan guru. Permasalahan lain yang ditemukan adalah kemandirian siswa tergolong rendah. Rendahnya kemandirian siswa ditandai dengan adanya siswa yang malu bertanya apabila menghadapi kesulitan memahami materi pelajaran; siswa pasif dalam kegiatan belajar mengajar; dan adanya siswa menyontek pada saat ujian semester.

\section{Hasil Belajar}

Seseorang yang telah melakukan kegiatan belajar, dalam dirinya akan terjadi perubahan perilaku yang disebut dengan hasil belajar. Sudjana
(2012, p. 3) menjelaskan bahwa hasil belajar pada hakikatnya adalah perubahan tingkah laku pada siswa setelah mengikuti proses pembelajaran. Di samping itu, Abdurrahman (2003, p.37) mendefinisikan hasil belajar sebagai kemampuan yang diperoleh siswa setelah melalui kegiatan belajar.

Berdasarkan pendapat tersebut, dapat disimpulkan bahwa hasil belajar adalah suatu kemampuan yang diperoleh siswa, ditandai dengan perubahan perilaku setelah menjalani proses pembelajaran. Perubahan tingkah laku individu tersebut relatif menetap sebagai hasil interaksi dengan lingkungan. Dengan kata lain, seseorang dinyatakan telah mencapai hasil belajar jika pada dirinya terjadi perubahan tertentu melalui proses pembelajaran.

Hasil belajar menunjukkan tingkat kemampuan dan penguasaan kompetensi dari setiap mata pelajaran yang bersifat esensial dan fungsional bagi siswa, sehingga memungkinkan bagi mereka untuk belajar lebih lanjut dalam rangka pembentukan kepribadian. Hasil belajar sesuai dengan tujuan dan bidang tertentu dapat diukur atau diketahui dengan cara melakukan penilaian yang menunjukan atas sejauh mana suatu kemampuan telah tercapai baik dinyatakan dengan angka, huruf ataupun pernyataan. Dalam pendidkan formal, hasil belajar dapat dilihat dari rapor.

Rapor merupakan buku laporan dari penilaiana guru terhadap siswa setelah mengikuti proses pembelajaran dalam periode tertentu. Rapor dapat digunakan untuk melihat kemajuan dan perkembangan siswa; bahan memetakan dan memperbaiki kegiatan pembelajaran supaya hasil belajar lebih maksimal; dan sebagai bentuk komunikasi pihak sekolah dengan orang tua untuk meninjau kemajuan hasil belajar siswa (Jacobsen et. al, 2009, p. 308).

Pembagian hasil belajar meliputi beberapa ranah yang biasa disebut dengan dengan taksonomi Bloom. Taksonomi belajar tersebut merupakan suatu kerangka untuk mengklasifikasikan pernyataan-pernyataan yang digunakan untuk mempredikasi dan mengukur kemampuan siswa setelah menjalani proses pembelajaran. Bloom (1956, p. 7) mengklasifikasikan hasil belajar menjadi tiga ranah, yaitu: ranah kognitif (domain 
cognitive), ranah afektif (affective domain), dan ranah psikomotorik (psychomotor domain).

Ranah kognitif merupakan bagian dari hasil belajar yang berisi perilaku-perilaku mencakup aspek intelektual, seperti pengetahuan, pengertian, dan keterampilan berpikir. Bloom (1956, p. 18) membagi hasil belajar pada ranah kognitif menjadi enam tingkatan, yaitu: pengetahuan (knowledge), pemahaman (comprehension), penerapan (application), analisis (analysis), sintesis (synthesis), dan evaluasi (evaluation).

Pengetahuan adalah kemampuan yang paling rendah dan dasar dalam kawasan kognitif. Pengetahuan merupakan kemampuan untuk mengenal atau mengingat kembali sesuatu objek, ide, prosedur, prinsip atau teori yang pernah ditemukan dalam pengalaman tanpa memanipulasikannya dalam suatu bentuk atau simbol, sebagaimana Bloom (1956, p. 62) menjelaskan bahwa "Knowledge as defined here includes those behaviors and test situations which emphasize the remembering, either by recognition or recall, of ideas, material, or phenomena". Pengetahuan yang tersimpan dalam memori ingatan, digali pada saat dibutuhkan melalui pengingatan kembali (recall) atau pengenalan kembali (recognitiom). Tingkatan kedua setelah pengetahuan adalah pemahaman.

Pemahaman mencakup kemampuan untuk menangkap makna dan arti dari materi yang dipelajari. Kemampuan ini dapat dinyatakan dengan menguraikan isi pokok dari suatu bacaan; mengubah data yang disajikan dalam bentuk lainnya dengan makna yang sama; dan membuat perkiraan tentang kecenderungan yang tampak dalam data tertentu, misalnya dalam bentuk grafik atau bagan. Pemahaman merupakan tingkatan kognitif yang lebih rendah dari penerapan.

Penerapan mencakup pada kemampuan untuk menerapkan suatu kaidah atau teori dalam suatu kasus atau problem yang konkret dan baru. Dengan kata lain, Penerapan merupakan kemampuan untuk menggunakan konsep, prinsip, prosedur atau teori pada situasi tertentu. Seseorang menguasai kemampuan ini jika dapat memberi contoh, menggunakan, mengklasifikasikan, menyelesaikan, dan mengidentifikasikan suatu yang sudah dipelajari. Kemampuan ini setingkat lebih tinggi dengan pemahaman karena memahami suatu kaidah atau teori belum tentu bisa menerapkan dalam kasus tertentu. Kemampuan yang lebih tinggi dari penerapan adalah amalisis.

Analisis mencakup kemampuan untuk merinci suatu kesatuan ke dalam bagian-bagian terkecil, sehingga struktur keseluruhan dapat dipahami secara komprehensif. Kemampuan dinyatakan dengan penganalisaan bagia-bagian disertai dengan hubungan yang memiliki keterkaitan pada bagian tersebut. Berkaitan dengan analisis, Bloom (1956, p.144) menjelaskan bahwa:

...Analysis emphasizes the breakdown of the material into its constituent parts and detection of the relationships of the parts and of the way they are organized. It may also be directed at the techniques and devices used to convey the meaning or to establish the conclusion of a communication (Bloom, 1956, p. 144)..

Tingkatan yang lebih tinggi setelah analisis adalah sintesis. Bloom (1956, p. 162) menjelaskan bahwa yang dimaksud dengan sintesis adalah:

... the putting together of elements and parts so as to form a whole. This is a process of working with elements, parts, etc., and combining them in such a way as to constitute a pattern or structure not clearly there before. Generally this would involve a recombination of parts of previous experience with new material, reconstructed into a new and more or less well-integrated whole (Bloom, 1956, p. 162).

Sintesis meliputi kemampuan membentuk suatu kesatuan atau pola baru. Jenjang sintesis merupakan kemampuan untuk mengintegrasikan bagian-bagian yang terpisah menjadi suatu keseluruhan yang terpadu, atau menggabungkan bagian-bagian sehingga menjadi pola yang berkaitan secara logis, atau mengambil kesimpulan dari peristiwa-peristiwa yang ada hubungannya satu dengan yang lainnya. Level yang lebih tinggi di atas sintesis adalah evaluasi.

Evaluasi mencakup kemampuan untuk memberikan penilaian terhadap solusi, gagasan, dan metodologi dengan menggunakan 
kriteria yang cocok atau standar yang ada untuk memastikan nilai efektivitas atau manfaatnya. Mengenai evaluasi Bloom (1956, p. 185) menjelaskan "Evaluation is defined as the making of judgments about the value, for some purpose, of ideas, works, solutions, methods, material, etc".

Evaluasi dibedakan menjadi dua kategori, yakni: (a) evaluasi berdasarkan bukti internal yaitu evaluasi terhadap ketetapan komunikasi berdasarkan logika, konsistensi, dan kriteria-kriteria internal lain misalnya, menunjukkan kesalahan-kesalahan logika dalam suatu argumen; dan (b) evaluasi berdasarkan bukti eksternal yaitu evaluasi terhadap materi berdasarkan kriteria yang ditetapkan atau diingat, misalnya membandingkan teori-teori, generalisasi-generalisasi, dan fakta-fakta pokok tentang kebudayaan tertentu.

Ranah afektif (affective domain) berisi perilaku-perilaku yang menekankan pada aspek perasaan dan emosional, seperti minat, sikap, apresiasi, dan cara penyesuaian diri. Menurut Jacobsen, et.al (2009: , pp. 92-93), ranah afektif terdiri dari beberapa tingkatan. Pertama, menerima (receiving). Menerima (receiving) ialah kepekaan seseorang dalam menerima rangsangan (stimulus) dari luar yang datang kepada dirinya dalam bentuk masalah, situasi, gejala dan lainlain, termasuk dalam jenjang ini misalnya ialah kesadaran dan keinginan untuk menerima stimulus, mengontrol dan menyeleksi gejala-gejala atau rangsangan yang datang dari luar. Menerima (receiving) juga sering diberi pengertian sebagai kemauan untuk memperhatikan suatu kegiatan atau suatu objek. Misalnya, mendengarkan dengan sungguh-sungguh; menunjukkan kesadaran akan pentingnya belajar dan bersikap disiplin serta mandiri.

Kedua, menanggapi (responding). Menanggapi mengandung arti adanya partisipasi aktif dalam suatu kegiatan. Kemampuan menanggapi mencakup kemampuan yang dimiliki oleh seseorang untuk mengikutsertakan dirinya secara aktif dalam fenomena tertentu dan membuat reaksi terhadapnya dengan salah satu cara. Siswa secara aktif dan interaktif dalam kegiatan pembelajaran. Misalnya, siswa berminat mempelajari lebih jauh atau menggali lebih dalam lagi tentang kedisiplinan; berpartisifasi dalam kegiatan diskusi di kelas; menunjukkan minat dalam mata pelajaran; dan mengikuti aturan-aturan sekolah.

Ketiga, menghargai (valuing). Menghargai mencakup kemampuan memberikan nilai atau penghargaan terhadap suatu kegiatan atau objek. Dalam kaitan dengan proses belajar mengajar, siswa tidak hanya mau menerima nilai yang diajarkan, tetapi mereka telah mampu untuk menilai konsep atau fenomena, yaitu baik atau buruk. Nilai itu telah mulai dicamkan (internalized) dalam dirinya. Kemampuan menghargai dapat dinyatakan dalam bentuk perkataan atau perbuatan, misalnya kemauan yang kuat pada diri siswa untuk berlaku disiplin dan menghargai peranan ilmu pengetahuan dalam kehidupan sehari-hari. Hasil belajar menghargai meliputi perilaku yang konsisten dan cukup stabil dengan sikap batin siswa, contohnya mengungkap dengan positif terhadap pameran lukisan.

Keempat, mengatur (organization). Mengatur ialah mempertemukan perbedaan nilai, sehingga terbentuk nilai baru yang universal, yang membawa kepada perbaikan umum. Mengatur atau mengorganisasikan merupakan pengembangan nilai dari ke dalam satu sistem organisasi, termasuk di dalamnya hubungan satu nilai dengan nilai lain, pemantapan dan prioritas nilai yang telah dimilikinya. Contoh hasil belajar afektif jenjang organization ialah siswa mendukung penegakan disiplin nasional. Mengatur dan mengorganisasikan merupakan jenjang sikap atau nilai yang lebih tinggi lagi ketimbang receiving, responding dan valuing.

Kelima, karakterisasi berdasarkan suatu nilai atau kompleks nilai (value complex). Karakterisasi dengan suatu nilai atau kompleks nilai (value complex) ialah keterpaduan semua sistem nilai yang telah dimiliki seseorang yang mempengaruhi pola kepribadian dan tingkah lakunya. Di sini proses internalisasi nilai telah menempati tempat tertinggi dalam suatu hirarki nilai. Nilai itu telah tertanam secara konsisten pada sistemnya dan telah mempengaruhi emosionalnya. Hal ini ialah merupakan tingkatan afektif tertinggi, karena sikap batin siswa telah benar-benar bijaksana. Ia telah memiliki philosophy of life yang mapan. Jadi, pada jenjang ini siswa telah memiliki sistem nilai yang mengotrol tingkah lakunya untuk suatu waktu yang cukup 
lama, sehingga membentuk karakteristik "pola hidup" tingkah lakunya menetap, konsisten dan dapat diramalkan.

Ranah psikomotorik mencakup perilakuperilaku yang menekankan aspek keterampilan motorik seperti tulisan tangan, mengetik, berenang, dan mengoperasikan komputer. Harrow (1972,p.32) mengklasifikasikan ranah psikomotorik ke dalam beberapa tingkatan. Pertama, gerakan refleks (reflex movements). Gerakan refleks merupakan respon terhadap beberapa stimulus tanpa kemauan yang disadari pada diri pembelajar. Gerakan tersebut tidak didasarkan pada niat yang disengaja, namun dianggap sebagai suatu hal yang penting mendasar dalam suatu aktivitas. Misalnya mata berkedip secara tidak disadari pada saat sesuatu jatuh di atas mata.

Kedua, gerakan dasar (basic-fundamental movements). Aktivitas gerakan dasar mencakup tidakan melacak benda secara visual, mencapai, memahami, memanipulasi sasaran dengan tangan, dan terus mengalami perkembangan yang ditandai dengan merangkak, menjalar, berjalan dan pada akhirnya berlari.

Ketiga, kemampuan persepsi (perceptual abilities). Tingkatan ini nampak berada pada ranah kognitif, namun berdasarkan hasil penelitian menegaskan bahwa gerakan dan persepsi merupakan dua hal yang tidak dapat dipisahkan. Kemampuan ini dapat membantu siswa menafsirkan stimulus yang diterimanya, dan memudahkan mereka menyesuaikan diri dengan kebutuhan yang dituntut oleh lingkungan.

Keempat, kemampuan fisik (physical abbilities). Kemampuan fisik merupakan kemampuan psikomotorik yang lebih tinggi dari kemampuan persepsi. Kemampuan ini mencakup stamina, kekuatan, keluwesan, dan ketangkasan, seperti lompat jauh dan bermain sepakbola serta jenis olahraga lainnya yang membutuhkan kontraksi otot. Dengan memanfaatkan kemampuan fisik tersebut, siswa dapat memenuhi tuntutan dari lingkungannya dan merupakan bagian penting dalam mengembangkan gerakan yang terampil.

Kelima, gerakan terampil (skill movements). Gerakan terampil bisa diartikan dengan kecakapan dalam mengerjakan suatu tugas atau bisa juga bermakna efisiensi usaha yang ditunjukkan siswa guna menyempurnakan geraka yang rumit, seperti membuat gambar peta dengan efektif.

Keenam komunikasi nondiskursif (nondiscursive communication). Pada tingkat komunikasi yang nondiskursif, masing-masing siswa mengkomunikasikan perasaan dan emosional melalui gerakan tubuh, seperti melakukan pantomin atau menari dalam mengkomunikasikan karya musikal.

\section{Kedisiplinan Belajar}

Kata disiplin dalam Kamus Besar Bahasa Indoensia (KBBI) bermakna tata tertib; ketaatan (kepatuhan) kepada peraturan. Menurut Darmono dkk (1994, p. 55) menjelaskan bahwa disiplin mengandung arti pengendalian dan pengarahan diri (self control and self direction). Individu dapat mengendalikan diri tanpa pengaruh dari luar. Pengendalian diri memiliki makna menguasai perilaku diri sendiri dengan berpegang pada norma-norma dan aturan-aturan yang sudah menjadi milik sendiri. Individu yang menguasai perilakunya sendiri adalah individu yang mempunyai kesadaran mematuhi segala peraturan dan nilai yang menjadi pedomannya. Individu tetap mematuhi peraturan yang berlaku meskipun tidak ada yang mengawasi atau mengancam dengan sanksi tertentu.

Hidayatullah (2010, p. 45) menjelaskan bahwa disiplin adalah suatu ketaatan didukung oleh kesadaran yang sungguh-sungguh untuk melaksanakan tugas dan kewajiban serta bertindak sesuai dengan aturan-aturan yang berlaku dalam lingkungan tertentu.

Berdasarkan pendapat tersebut, dapat disimpulkan bahwa disiplin adalah kepatuhan individu untuk melaksanakan aturan-aturan yang berlaku dalam kelompok sosial; mengendalikan dan mengarahkan diri dalam bertingkah laku dengan penuh kesadaran. Disiplin siswa di sekolah, dapat diartikan dengan ketaatan dan kepatuhan siswa melaksanakan aturan-aturan yang berlaku dalam lingkungan sekolah secara konsisten dan bersungguh-sungguh guna kelancaran proses belajar mengajar.

Kedisiplinan berkaitan dengan pengendalian diri. Kedisiplinan yang sudah terbentuk dalam pribadi anak, diharapkan dapat meringankan beban orang tua untuk mengontrol perilaku 
yang negatif dan di lingkungan sekolah, disiplin dapat mengarahkan dan mengendalikan aktivitas anak dalam proses belajar mengajar, sehingga hasil belajar meningkat.

Anak yang berdisiplin adalah anak yang dapat mengontrol diri (self control). Kontrol diri dapat diketahui dari beberapa indikator, antara lain: berkemampuan mengendalikan perilaku dan emosi, mematuhi peraturan yang berlaku, mencegah diri dari perilaku yang tidak sesuai, bersabar, dan fokus mengerjakan tugas. Sebagaimana Bergin \& Bergin (2012, p. 252) mengatakan bahwa "self control the ability to control one's own behavior and emotions, obey rules, inhibit inappropriate action, and focus attention".

Orang yang berdisiplin memiliki ciri melakukan sesuatu tugas atau kegiatan dengan teratur sesuai waktu yang ditentukan tanpa ada paksaan atau kesadaran sendiri (Rusyan, Sutisna \& Hidayat, 2000, pp. 67-69). Dalam konteks lingkungan sekolah, anak yang berdisiplin adalah anak yang taat terhadap tata tertib sekolah. Tata tertib sekolah tersebut meliputi: (1) mematuhi peraturan sekolah; (2) mengindahkan petunjukpetunjuk berlaku di sekolah; (3) tidak berbohong; (4) berkelakuan baik; (5) mengerjakan tugas yang diberikan oleh guru; (6) tepat waktu masuk kelas sesuai jadwal pelajaran; (7) tidak meninggalkan kelas saat berlangsung proses belajar mengajar dan; (8) tidak membuat keributan dalam kelas supaya tidak menggangu konsentrasi saat proses belajar mengajar.

Abu dkk (1989, p. 197) mengidentifikasi beberapa indikator ketertiban sebagai bagian dari sikap disiplin siswa di sekolah, antara lain: masuk dan pulang sesuai jam pelajaran; mengenakan pakaian seragam sesuai ketentuan dari pihak sekolah; membayar uang sekolah; bertegur sapa; sederhana dalam berhias; menepati janji; tepat waktu; mematuhi ketentuan-ketentuan yang ada di sekolah; dan sopan santun dalam pergaulan.

Berdasarkan beberapa pendapat tersebut, dapat disimpulkan bahwa kedisiplinan siswa di sekolah dapat ditinjau dari beberapa aspek, yaitu ketertiban, kemampuan mengendalikan diri, dan kemampuan berkonsentrasi. Ketertiban indikatornya adalah datang dan pulang tepat waktu; hadir di kelas sesuai jadwal pelajaran yang ditentukan pihak sekolah dan; tidak meninggalkan kelas saat berlangsung proses belajar mengajar. Aspek kemampuan mengendalikan diri terdiri atas beberapa indikator antara lain: mengumpulkan tugas tepat waktu; bersikap tenang dalam proses belajar mengajar dan; tidak berbohong (jujur). Aspek kemampuan berkonsentrasi mempunyai indikator: mengerjakan tugas dengan baik; fokus mengerjakan tugas; memperhatikan penjelasan guru dan; aktif dalam kegiatan belajar mengajar.

\section{Kemandirian Belajar}

Kemandirian dalam bahasa Indonesia berasal dari kata mandiri yang memiliki arti keadaan dapat berdiri sendiri dan tidak bergantung pada orang lain. Dalam referensi bahasa asing, kemandirian sering disebut dengan autonomy.

Kemandirian berkaitan dengan kebebasan sebagaimana O'Neill (2003, p. IX) menyatakan bahwa "autonomy is usually identified with individual independence". Sejalan dengan pendapat tersebut, Santrock (2003: 190) mengatakan bahwa kemandirian berkaitan dengan mengatur diri sendiri dan bebas. Kemandirian yang merujuk pada kebebasan (independence) mengacu kepada kapasitas individu untuk memperlakukan diri sendiri. Di samping itu, Basri (1996, p. 53) menjelaskan bahwa kemandirian adalah kondisi seseorang dalam kehidupannya yang mampu memutuskan atau mengerjakan sesuatu tanpa bantuan orang lain.

Berdasarkan uraian tersebut, dapat disimpulkan bahwa kemandirian adalah suatu sikap dan perilaku individu mengatur diri sendiri dan tidak bergantung pada orang lain untuk menyelesaikan semua tugas dalam kehidupannya, termasuk dalam belajar.

Kemandirian merupakan tugas perkembangan anak pada masa remaja yang perlu diperhatikan oleh orang tua dan guru. Dalam konteks pendidikan, kemandirian sangat penting untuk dikembangkan pada siswa guna memperlancar proses belajar mengajar, sehingga tujuan pendidikan yang sudah ditentukan dapat tercapai dengan baik.

Maslow (1993, p. 16) memandang bahwa seseorang dikatakan memiliki kemandirian apabila terdapat pada dirinya sikap dan perilaku yang 
dapat mengambil keputusan sendiri, mengatur diri sendiri, berinisiatif, dan bertanggung jawab dalam segala hal.

Sanan \& Yamin (2010, pp. 83-84) menambahkan bahwa anak yang mandiri memiliki beberapa indikator, antara lain (1) percaya pada kemampuan diri sendiri; (2) memiliki motivasi intrinsik atau dorongan untuk bertindak yang berasal dari dalam individu; (3) kreatif dan inovatif; (4) bertanggung jawab atau menerima konsekuensi terhadap risiko tindakannya dan; (5) tidak bergantung pada orang lain (berusaha tidak bantuan orang lain, tetap mandiri).

\section{Metode Penelitian}

Jenis Penelitian

Desain penelitian ini adalah expost facto dengan jenis penelitian assosiatif. Penelitian ini tergolong expost facto karena data diambil apa adanya tanpa ada perlakuan. Penelitian ini termasuk assosiatif karena berupaya mencari pengaruh kedisiplinan dan kemandirian belajar terhadap hasil belajar.

\section{Waktu dan Tempat Penelitian}

Penelitian ini dilaksanakan di Madrasah Aliyah yang berada di Kecamatan Praya Kabupaten Lombok Tengah. Waktu penelitian berlangsung mulai bulan Agustus 2013 sampai dengan Pebruari 2014.

Populasi dan Sampel Penelitian

Populasi penelitian ini adalah seluruh siswa kelas XI jurusan IPS Madrasah Aliyah di Kecamatan yang berjumlah 600 siswa.

Pengambilan sampel menggunakan teknik simple random sampling. Penentuan jumlah sampel menggunakan teknik yang dikembangkan oleh Issac dan Michael. Besarnya sampel pada penelitian ini berjumlah 221 siswa.

Variabel Penelitian

Variabel pada penelitian ini terdiri dari variabel independen dan dependen. Variabel independen ada dua, yaitu kedisiplinan dan kemandirian belajar. Sedangkan yang menjadi variabel dependen adalah hasil belajar Ekonomi.

Teknik dan Instrumen Penelitian

Pengumpulan data dalam penelitian ini menggunakan kuesioner dan dokumentasi.
Teknik kuesioner digunakan untuk mengumpulkan data kedisiplinan dan kemandirian belajar siswa dan teknik dokumentasi digunakan untuk mengumpulkan data hasil belajar Ekonomi yang ditulis dalam rapor semester terakhir.

Instrumen yang digunakan adalah instrumen angket atau kuesioner. Kuesioner pada penelitian ini terdiri atas dua macam, yaitu kuesioner variabel kedisiplinan dan variabel kemandirian. Skala instrumen yang digunakan adalah skala likert. Setiap butir pernyataan angket memiliki empat alternatif jawaban, yaitu selalu (skor 4), sering (skor 3), kadang-kadang (skor 2), tidak pernah (skor 1).

\section{Teknik Analisis Data}

Teknik analisis data menggunakan statistik deskriptif dan inferensial. Analisis deskriptif yang digunakan dalam penelitian ini adalah skor minimum, skor maksimum, rerata, median, mode, simpangan baku, dan persentase. Data disajikan dalam bentuk tabel dan histogram. Analisis deskriptif ini digunakan untuk memaparkan karakteristik data hasil penelitian dan menjawab permasalahan deskriptif..

Analisis selanjutnya adalah analisis inferensial. Analisis ini digunakan untuk mengambil kesimpulan dari sampel untuk diberlakukan pada populasi.

Analisis inferensial pada penelitian ini menggunakan uji t untuk mengetahui pengaruh kedisiplinan belajar terhadap hasil belajar siswa dan pengaruh kemandirian belajar terhadap hasil belajar. Uji lain yang digunakan juga adalah uji $F$ untuk mengetahui pengaruh kedisiplinan dan kemandirian belajar terhadap hasil belajar siswa.

\section{Hasil Penelitian dan Pembahasan}

Hasil penelitian mencakup penyebaran data yang meliputi skor rata-rata atau mean, median, mode, standar deviasi, skor minimum, dan skor maksimum disertai histogram dari masing-masing variabel.

Pertama, hasil belajar. Berdasarkan hasil analisis deskriptif diketahui bahwa nilai rata-rata dari 221 siswa pada mata pelajaran ekonomi adalah 80,33; nilai tertinggi mencapai 95 ; dan nilai terendah mencapai 70 .

Data hasil belajar siswa pada mata pelajaran ekonomi yang sudah terkumpul kemudian 
dikelompokkan berdasarkan kriteria ketuntasan minimal (KKM) sebesar 75. Apabila siswa mendapatkan nilai 75 atau lebih, maka siswa tersebut tergolong tuntas dalam belajarnya dan apabila siswa mendapatkan nilai di bawah 75 maka tergolong tidak tuntas. Berdasarkan hasil penghitungan, pengkategorian hasil belajar siswa dapat dilihat pada tabel berikut:

Tabel 1. Kategori Hasil Belajar Siswa pada Mata Pelajaran Ekonomi Berdasarkan KKM

\begin{tabular}{clcc}
\hline $\begin{array}{c}\text { Nilai } \\
\text { siswa }\end{array}$ & Kategori & F & Persentase \\
\hline$\geq 75$ & Tuntas & 199 & $90,05 \%$ \\
$<75$ & Tidak tuntas & 22 & $9,95 \%$ \\
\hline
\end{tabular}

Tabel 1 di atas menunjukkan bahwa sebanyak 199 siswa masuk dalam kategori tuntas dalam belajar dan sebanyak 22 siswa masuk dalam hasil belajar dengan kategori tidak tuntas.

Ketuntasan belajar dari 221 siswa pada mata pelajaran ekonomi Madrasah Aliyah di Kecamatan Praya Kabupaten Lombok Tengah dapat juga digambar dalam bentuk histogram sebagai berikut:

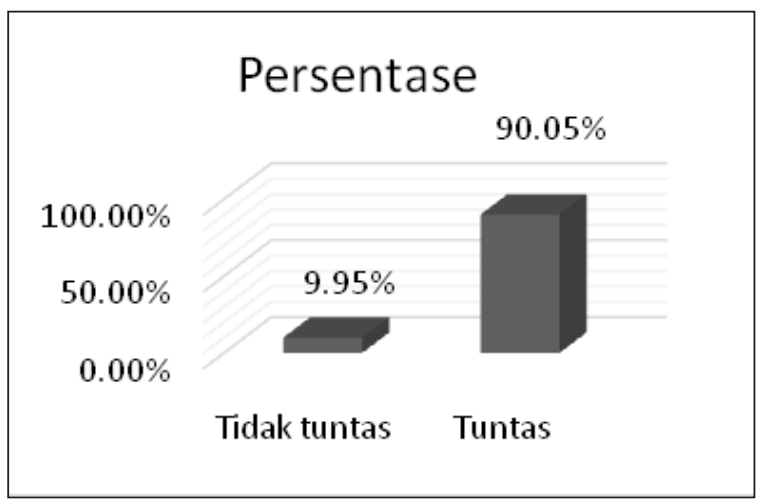

Gambar 1. Persentase Ketuntasa Belajar Siswa pada Mata Pelajaran Ekonomi

Gambar 1 di atas menunjukkan bahwa siswa yang tergolong tidak tuntas dalam belajar sebesar $9,95 \%$ dan siswa yang tuntas dalam belajar sebesar 90,05\%. Hal ini menunjukkan bahwa ketuntasan belajar siswa mencapai lebih dari $75 \%$ yang berarti siswa sudah menguasai tujuan pembelajaran sesuai target guru.

Kedua, kedisiplinan belajar. Berdasarkan hasil analisis deskriptif tentang kedisiplinan belajar dari 221 siswa Madrasah Aliyah di Kecamatan Praya adalah skor rata-rata kedisiplinan siswa sebesar 44,39 dengan skor standar deviasi sebesar 11,544; skor tertinggi adalah 70 dan skor terendah adalah 25 .

Data tentang kedisiplinan yang terkumpul kemudian dikelompokkan menjadi empat kategori sebagai berikut.

Tabel 2. Kategori Kedisiplinan Belajar Siswa

\begin{tabular}{clc}
\hline $\begin{array}{c}\text { Skor } \\
\text { siswa }\end{array}$ & \multicolumn{1}{c}{ Kategori } & Frekuensi \\
\hline & & \\
$\geq 57$ & Sangat tinggi & 41 \\
$45-56$ & Tinggi & 56 \\
$33-44$ & Rendah & 89 \\
$<33$ & Sangat rendah & 35 \\
\hline
\end{tabular}

Berdasarkan tabel 2 menunjukkan bahwa kedisiplinan belajar siswa dengan kategori sangat tinggi sebanyak 41; kategori tinggi sebanyak 56, kategori rendah sebanyak 89; dan kategori sangat sebanyak 35.

Kategori kedisiplinan belajar dari 221 siswa kelas XI jurusan IPS Madrasah Aliyah di Kecamatan Praya dapat juga dilihat dalam bentuk histogram berikut.

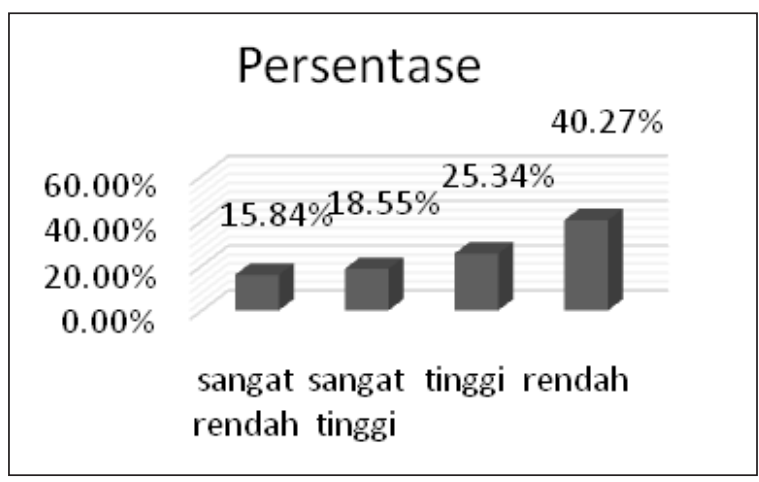

Gambar 2. Persentase Kedisiplinan Belajar Siswa

Gambar 2 di atas menunjukkan bahwa persentase kedisiplinan belajar siswa pada kategori sangat rendah sebesar $15,84 \%$; kategori rendah adalah 40,27\%; kategori tinggi mencapai $25,34 \%$; dan kategori sangat tinggi mencapai $18,55 \%$.

Kondisi ini menjadi keprihatinan dan bahan introspeksi diri dari guru untuk meningkatkan kedisiplinan siswa dengan cara penertiban terhadap aturan madrasah atau kelas. Aturan/tata tertib madrasah merupakan salah satu alat untuk melatih anak didik mempraktekkan disiplin di 
madrasah. Tata tertib dan disiplin madrasah harus diusahakan menunjang dinamika madrasah dalam semua kegiatannya, karena secara eksplisit mencakup sanksi-sanksi yang akan diterima jika terjadi pelanggaran terhadap ketentuan-ketentuan yang telah ditetapkan madrasah.

Ketiga, kemandirian belajar. Berdasarkan hasil analisis deskriptif menunjukkan bahwa skor tertinggi adalah 89; skor terendah mencapai 27; dan skor rata-rata kemandirian belajar siswa mencapai 73,33 .

Data tentang kemandirian belajar siswa yang terkumpul kemudian dikelompokkan menjadi empat kategori sebagai berikut.

Tabel 4.3. Kategori Kemandirian Belajar Siswa

\begin{tabular}{clc}
\hline Skor siswa & \multicolumn{1}{c}{ Kategori } & Frekuensi \\
\hline$\geq 73$ & Sangat tinggi & 44 \\
$56-72$ & Tinggi & 53 \\
$38-55$ & Rendah & 92 \\
$<38$ & Sangat rendah & 32 \\
\hline
\end{tabular}

Berdasarkan tabel 3 menunjukkan bahwa kemandirian belajar siswa dengan kriteria sangat rendah berjumlah 32; kriteria rendah berjumlah 92; kriteria tinggi sebanyak 53; dan kriteria sangat tinggi sebanyak 44. Kategori kemandirian belaja siswa Madrasah Aliyah di Kecamatan Praya Kabupaten Lombok Tengah dapat juga dilhat pada gambar histogram berikut ini:

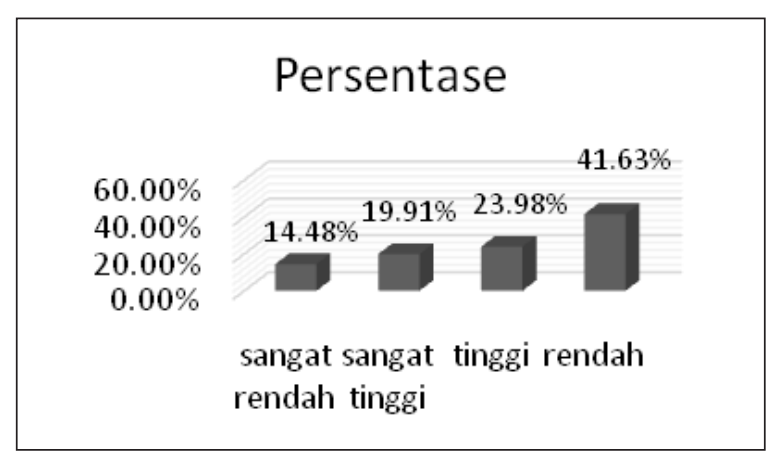

Gambar 3. Persentase Kemandirian Belajar Siswa

Berdasarkan gambar 3 di atas, menunjukkan bahwa kedisiplinan belaja siswa pada kategori sangat rendah sebesar $14,48 \%$; kategori rendah sebesar $41,63 \%$, kategori tinggi sebesar 23,98\%; dan kategori sangat tinggi mencapai 19,91\%. Adanya kenyataan bahwa kemandirian siswa Madrasah Aliyah di Kecamatan Praya paling tinggi berada pada kategori rendah dapat dijadikan oleh guru dan pihak yang terlibat dalam pendidikan guna memperbaiki pendidikan dan proses pembelajaran dengan tindakan riil melalui berbagai program atau melalui kegiatan ekstrakurikuler.

Pengaruh Kedisiplinan Belajar terhadap Hasil Belajar

Hasil belajar merupakan suatu kemampuan yang diperoleh siswa, ditandai dengan perubahan perilaku setelah menjalani proses pembelajaran. Perubahan tingkah laku individu tersebut relatif menetap sebagai hasil interaksi dengan lingkungan. Dengan kata lain, seseorang dinyatakan telah mencapai hasil belajar jika pada dirinya terjadi perubahan tertentu melalui proses pembelajaran.

Hasil belajar dipengaruhi oleh banyak faktor, antara lain faktor internal, faktor ekternal dan faktor pendekatan belajar (Syah, 2008, p. 132). Faktor internal mencakup keadaan atau kondisi dalam diri siswa yang meliputi jasmani dan rohani. Faktor eksternal mencakup faktor yang datang dari luar siswa, seperti kondisi lingkungan di sekitar siswa. Sedangkan faktor pendekatan belajar menyangkut berbagai jenis upaya belajar yang dilakukan siswa, meliputi strategi dan metode yang digunakan siswa untuk melakukan kegiatan pembelajaran terhadap materi-materi pelajaran.

Kedisiplinan belajar merupakan salah satu faktor yang mempengaruhi hasil belajar. Kedisiplinan mencakup kepatuhan dan ketaatan individu terhadap peraturan dan norma-norma yang berlaku pada suatu tempat termasuk dalam lembaga pendidikan seperti madrasah, berdasarkan kemampuan mengendalikan diri (self control).

Kedisiplinan belajar juga merujuk pada efisiensi waktu yang ditunjukkan dengan kemampuan siswa menyelesaikan tugas-tugas yang diberikan oleh guru dengan tepat waktu dan hasil yang baik. Adanya kedisipinan yang terbentuk pada kepribadian siswa dapat meningkatkan produktivitas belajar dan menumbuhkan kreativitas siswa sehingga siswa menjadi aktif dalam kegiatan belajar mengajar di kelas.

Adanya produktivitas siswa dalam belajar sebagai wujud dari kedisiplinan diharapkan dapat meningkatkan hasil belajar siswa. Berdasarkan 
hasil analisis dalam penelitian ini menunjukkan bahwa kedisiplinan berpengaruh positif terhadap hasil belajar. Hal ini dibuktikan dengan nilai $\mathrm{t}_{\text {hitung }}$ adalah 5,217 pada taraf signifikansi 0,000 lebih kecil dari derajat kesalahan 0,05. Besarnya sumbangan kedisiplinan belajar terhadap hasil belajar siswa sebesar 0,281 . Hal ini menunjukkan $28,1 \%$ variabel hasil belajar siswa dipengaruhi oleh kedisiplinan belajar, sedangkan 71,9\% dipengaruhi oleh variabel lain yang tidak dibahas pada penelitian ini.

Hasil penelitian ini juga didukung oleh penelitian terdahulu. Arigiyati (2010, p. 930) dalam penelitiannya menyimpulkan bahwa ada pengaruh yang signifikan antara kedisiplinan terhadap prestasi atau hasil belajar dan sumbangan variabel kedisiplinan terhadap prestasi atau hasil belajar adalah 39,7\%. Penelitian lain juga menyimpulkan hal yang sama, penelitian yang dilakukan oleh Saputro \& Pardiman (2012, pp. 78-79) menemukan bahwa terdapat pengaruh positif dan signifikan disiplin belajar terhadap prestasi atau hasil belajar yang ditunjukkan dengan nilai $t_{\text {hitung }}$ lebih besar dari $t_{\text {tabel }}$ yaitu: 7,780 $>1,984$ dengan koefisien determinasi sebesar 0,345.

Adanya kesimpulan bahwa kedisiplinan berpengaruh positif terhadap hasil belajar merupakan bahan pertimbangan bagi guru dan pihak madrasah untuk senantiasa membentuk kedisiplinan siswa. Pembentukan kedisiplinan siswa dapat dilakukan dengan cara penertiban terhadap aturan kelas dan madrasah. Aturan/tata tertib kelas dan madrasah merupakan salah satu alat untuk melatih siswa mempraktekkan disiplin. Tata tertib dan disiplin kelas dan madrasah harus diusahakan menunjang dinamika dalam semua kegiatan, karena secara eksplisit mencakup sanksi-sanksi yang akan diterima jika terjadi pelanggaran terhadap ketentuan-ketentuan yang telah ditetapkan. Tujuan disiplin siswa adalah untuk mengontrol tingkah laku siswa seperti yang dikehendaki, agar tugas-tugas di madrasah dapat berjalan dengan optimal. Selain itu siswa belajar hidup dengan pembiasaan yang baik, positif dan bermanfaat bagi dirinya dan lingkungannya, sehingga perkembangan dan pertumbuhan siswa meningkat.
Pengaruh Kemandirian Belajar terhadap Hasil Belajar

Hasil belajar merupakan perubahan yang terjadi pada diri siswa mencakup perubahan kognitif, afektif, dan psikomotorik. Hasil belajar juga diartikan dengan hasil yang dicapai oleh siswa selama berlangsungnya proses belajar mengajar dalam jangka waktu tertentu. Umumnya hasil belajar dalam sekolah berbentuk pemberian nilai dari guru kepada siswa sebagai indikasi sejauh mana siswa telah menguasai materi pelajaran, biasanya hasil belajar ini dinyatakan dalam bentuk angka, huruf atau kalimat pada periode tertentu.

Hasil belajar dipengaruhi oleh banyak faktor, antara lain: faktor internal, faktor ekternal, dan faktor pendekatan belajar (Syah, 2008, p. 132). Faktor internal berkaitan dengan faktor yang mempengaruhi hasil belajar berasal dalam individu mencakup rohani dan fisik. Faktor ekternal berkaitan dengan faktor yang berasal dari luar individu yang mencakup keadaan lingkungan madrasah ataupun rumah. Sedangkan faktor pendekatan belajar mencakup metode atau strategi yang digunakan siswa dalam belajar untuk memudahkan memahami materi pelajaran.

Kemandirian merupakan salah satu faktor yang mempengaruhi hasil belajar berasal dari internal siswa. Kemandirian meliputi sikap dan perilaku individu mengatur diri sendiri dan tidak bergantung pada orang lain untuk menyelesaikan semua tugas dalam kehidupannya, termasuk dalam belajar. Kemandirian siswa dalam belajar dilakukan atas dorongan internal dari individu tanpa bergantung pada orang lain untuk menguasai kompetensi guna mengatasi suatu masalah. Dengan memiliki kemandirian belajar, siswa dapat mengerjakan tugas-tugasnya dengan penuh percaya diri diserta rasa tanggungjawab yang tinggi dan mampu mengatasi masalah yang muncul pada dirinya.

Kemandirian siswa dalam belajar dapat menguntungkan dalam proses pembelajaran di kelas karena beberapa hal: (a) siswa cenderung belajar lebih baik dengan pengawasannya sendiri; (b) mampu memantau, mengevaluasi, dan mengatur belajarnya secara efektif; (c) menghemat 
waktu dalam menyelesaikan tugas yang diberikan guru; dan (d) mengatur belajar dan waktu secara efisien.

Siswa yang memiliki kemandirian tinggi tentu akan mencapai hasil belajar yang maksimal. Hasil belajar yang dimiliki oleh siswa yang mandiri lebih tinggi daripada siswa dengan mandiri yang rendah. Oleh karena itu, dengan adanya kemandirian belajar maka hasil belajar juga akan meningkat. Pernyataan tesebut sesuai dengan hasil analisis penelitian ini yaitu kemandirian berpengaruh positif terhadap hasil belajar. Hal ini ditunjukkan dengan nilai $t_{\text {hitung }}$ sebesar 2,361 pada taraf signifikansi 0,019 lebih kecil dari derajat kesaalahan 0,05 . Artinya bahwa kemandirian belajar siswa yang tinggi dapat meningkatkan hasil belajar. Selain itu, koefisien determinasi atau sumbangan kemandirian belajar terhadap hasil belajar siswa sebesar 0,212 . Hal ini berarti $21,2 \%$ hasil belajar dipengaruhi oleh kemandirian belajar siswa, sedangkan 78,8\% dipengaruhi oleh variabel lain yang tidak dibahas pada penelitian ini.

Hasil penelitian ini konsisten dengan kesimpulan penelitian terdahulu, seperti penelitian yang dilakukan oleh Rahmahwati (2013, p. 49) dengan kesimpulan bahwa terdapat pengaruh positif dan signifikan kemandirian belajar terhadap prestasi atau belajar yang ditunjukkan dengan thitung sebesar 2,884 pada taraf signifikansi 0,005. Dengan demikian dapat dikatakan bahwa kemandirin belajar berpengaruh terhadap hasil belajar, semakin tinggi kemandirian belajar siswa maka hasil belajar siswa meningkat, dan sebaliknya jika kemandirian belajar siswa rendah maka hasil belajar siswa juga rendah.

Adanya hasil penelitian yang menyimpulkan bahwa kemandirian belajar berpengaruh positif terhadap hasil belajar dapat menjadi bahan pertimbangan bagi guru dan pihak madrasah untuk menumbuhkan afektif tersebut dengan tindakan nyata atau riil melalui program-program ektrakurikuler maupun kegiatan belajar mengajar di kelas dengan strategi atau model pembelajaran yang efektif, seperti model pembelajaran selfdirected learning dan seven jumps.

Model pembelajaran self-directed learning merupakan suatu proses pembelajaran yang memberikan siswa kebebasan untuk berinisiatif, tanpa bantun orang lain untuk menganalisis kebutuhan belajar sendiri, merumuskan tujuan belajarnya sendiri, mengidentifikasi sumbersumber belajar, memilih dan melaksanakan strategi belajar yang sesuai serta mengevaluasi hasil belajarnya sendiri. Model pembelajaran ini dapat meningkatkan kemandirian belajar siswa, sebagaimana Rachmawati (2010, p. 177) dalam penelitiannya menyimpulkan bahwa terjadi peningkatan kemandirian belajar setelah diterapkan model self-directed learning dalam kegiatan pembelajaran.

Teknik seven jumps dapat juga meningkatkan kemandirian belajar siswa, sebagaimana hasil penelitian Mukminan, Nursa'ban \& Suparmini (2013, p. 263) menyimpulkan bahwa teknik seven jumps merupakan bantuan belajar dalam upaya memicu dan memacu kemandirian, disiplin dan inisiatif diri. Hal tersebut berdasarkan hasil analisis menggunakan perhitungan statistik korelasi Spearman Rank untuk pembelajaran menggunakan teknik seven jumps dengan kemandirian diperoleh nilai $\rho_{\text {hitung }(\alpha) \text { sebesar }}$ 0,511 dengan taraf signifikansi (p) 0,000. Jika $\mathrm{p}$ lebih besar dari $\alpha$ maka tidak ada hubungan antara kedua variabel, dan jika $p$ lebih kecil dari $\alpha$ maka ada hubungan antara kedua variabel. Hasil penelitian ini menunjukkan bahwa $\mathrm{p}$ lebih kecil dari $\alpha(0,000<0,05)$. Dengan demikian, dapat disimpulkan bahwa ada hubungan yang signifikan antara pembelajaran menggunakan teknik seven jumps dengan kemandirian belajar.

Pengaruh Kedisiplinan dan Kemandirian Belajar terhadap Hasil Belajar

Hasil analisis menunjukkan bahwa kedisiplinan dan kemandirian belajar merupakan faktor yang penting agar diperoleh hasil belajar yang optimal. Dengan adanya kedisiplinan dan kemandirian belajar yang tinggi maka akan diperoleh hasil belajar yang tinggi pula, begitu juga sebaliknya. Hal ini ditunjukkan dari hasil uji simultan dengan diperolehnya Fhitung 47,211 pada taraf signifikansi 0,000 lebih kecil dari derajat kesalahan 0,05. Yang artinya ada pengaruh positif kedisiplinan dan kemandirian belajar terhadap hasil belajar siswa pada mata pelajaran ekonomi kelas XI jurusan IPS Madrasah Aliyah di Kecamatan Praya Kabupaten Lombok Tengah. 
Besarnya sumbangan secara simultan dari kedisiplinan dan kemandirian belajar terhadap hasil belajar siswa pada mata pelajaran ekonomi sebagaimana terdapat pada kolom adjusted $R$ square adalah 0.296. Hal ini berarti $29,6 \%$ variabel hasil belajar dipengaruhi oleh variabel kedisiplinan dan kemandirian belajar, sedangkan $70,4 \%$ dipengaruhi oleh variabel lainnya tidak dibahas pada penelitian ini.

\section{Simpulan dan Saran}

Berdasarkan analisis data dan pembahasan, hasil penelitian dapat disimpulkan sebagai berikut:

1. Kedisplinan belajar berpengaruh positif terhadap hasil belajar Ekonomi siswa kelas XI jurusan IPS Madrasah Aliyah di Kecamatan Praya Kabupaten Lombok Tengah. Hal ini ditunjukkan dengan nilai $t_{\text {hitung }}$ sebesar 5,217 pada taraf signifikansi 0,000 . Hasil ini memberikan petunjuk bahwa semakin tinggi kedisiplinan siswa maka semakin tinggi pula hasil belajar ekonomi siswa. Koefisien determinasi kedisiplinan belajar terhadap hasil belajar siswa sebesar 0,281. Hal ini berarti $28,1 \%$ hasil belajar dipengaruhi oleh kedisiplinan belajar, sedangkan $71,9 \%$ dipengaruhi oleh variabel lain yang tidak dibahas pada penelitian ini.

2. Kemandirian belajar berpengaruh positif terhadap hasil belajar Ekonomi siswa kelas XI jurusan IPS Madrasah Aliyah di Kecamatan Praya Kabupaten Lombok Tengah. Hal ini ditunjukkan berdasarkan nilai $t_{\text {hitung }}$ sebesar 2,361 pada taraf signifikansi 0,019 . Hasil ini memberikan petunjuk bahwa semakin tinggi kemandirian siswa maka semakin tinggi pula hasil belajar ekonomi siswa. Koefisien determinasi atau sumbangan kemandirian belajar terhadap hasil belajar siswa sebesar 0,212. Hal ini berarti 21,2\% hasil belajar dipengaruhi oleh kemandirian belajar siswa, sedangkan 78,8\% dipengaruhi oleh variabel lain yang tidak dibahas pada penelitian ini.

3. Kedisiplinan dan kemandirian belajar berpengaruh positif terhadap hasil belajar siswa pada mata pelajaran ekonomi kelas XI jurusan IPS Madrasah Aliyah di Kecamatan Praya Kabupaten Lombok Tengah. Hal ini ditunjukkan nilai $\mathrm{F}_{\text {hitung }}$ sebesar 47,211 pada taraf signifikansi 0,000. Besarnya sumbangan kedisiplinan dan kemandirian belajar terhadap hasil belajar siswa adalah $29,6 \%$, sedangkan sisanya sebesar $70,4 \%$ dipengaruhi oleh variabel lainnya yang tidak dibahas dalam penelitian ini.

Berdasarkan simpulan hasil penelitian, saran yang perlu diperhatikan adalah sebagai berikut:

1. Bagi Guru

Para guru senantiasa berupaya memperbaiki strategi yang digunakan dalam meningkatkan hasil belajar siswa dan tetap berinovasi serta membuat kegiatan pembelajaran menjadi menarik dan kondusif. Kegiatan pembelajaran tidak hanya ditujukan untuk meningkatkan hasil belajar siswa pada ranah kognitif, guru juga harus membentuk sikap siswa termasuk disiplin dan mandiri.

\section{Bagi Kepala Madrasah}

Kepala madrasah hendaknya senantiasa tetap mengontrol dan melaksanakan evaluasi atas program-program pembelajaran yang berkaitan dengan pembentukan sikap dan hasil belajar siswa secara berkala. Evaluasi penting dilaksanakan agar program pembelajaran dapat terpantau efektivitasnya dan memperbaiki kekurangan program pembelajaran dengan berkoordinasi pada pihak guru. Selain itu, Kepala sekolah dan pihak yang terlibat dalam pendidikan mengusahakan pengadaan koleksi buku yang lengkap dan perpustakaan yang memadai agar siswa siswa dapat belajar secara mandiri.

\section{Daftar Pustaka}

Abdurrahman, M. (2003). Pendidikan anak berkesulitan belajar. Jakarta: Rineka Cipta.

Abu, Rifai dkk. (1989). Disiplin murid SMTA di lingkungan pendidikan formal pada beberapa propinsi di Indonesia. Jakarta: Depdikbud.

Arigiyati, Tri Astuti. (2010). Pengaruh kedisiplinan, motivasi belajar, dan dukungan orang tua terhadap prestasi belajar mata kuliah metode statistika mahaiswa program studi pendidikan matematika angkatan 2009. Jurnal Wacana Akademika, 3, 922-931. 
Basri, Hasan. (1996). Remaja berkualitas: problematika remaja dan solusinya. Yogyakarta. Pustaka Pelajar.

Bergin, Christi Crosby \& Bergin, David Allen. (2012). Child and adolescent development in your classroom. America: Wadsworth Cengage Learning.

Bloom, B.S. (Ed). (1956). Taxonomy of educational objectives: the classification of educational goals. New York: David Mckay Company Inc.

Darmono dkk. (1994). Pembinaan disiplin di lingkungan masyarakat kotamadya Medan. Jakarta: Depdikbud.

Depdiknas .(2003). Undang-Undang RI Nomor 20, Tahun 2003, tentang Sistem Pendidikan Nasional.

Depdiknas (2006). Peraturan Pemerintah RI Nomor 22 Tahun 2006, tentang Standar isi untuk Satuan Pendidikan Dasar Dan Menengah.

Harrow, A. J. (1972). A taxonomy of the psychomotor domain: a guide for developing behavioral objective. New York: Longman.

Hidayatullah, M.F. (2010). Pendidikan karakter: membangun peradaban bangsa. Surakarta: Yuma Pustaka.

Jacobsen et. al,. (2009). Methods for teaching: metode-metode pengajaran meningkatkan belajar siswa TK-SMA (Terjemahan Achmad Fawaid \& Khoirul Anam). Yogyakarta: Pustaka Pelajar.

Maslow, A.H. (1993). Motivasi dan kepribadian (Terjemahan Nurul Imam). Jakarta: PT. Pustaka Binaman Pressindo.
Mukminan, Nursa'ban, \& Suparmini (2013). Penggunaan teknik seven jumps untuk peningkatan kemandirian belajar mahasiswa. Jurnal Cakrawala Pendidikan universitas negeri yogyakarta. 2, 258- 265.

O'neill, O. (2003). Autonomy and trust in bioethics. New York: Cambridge University Press.

Rusyan, Sutisna \& Hidayat. (2000). Pendidikan budi pekerti. Jakarta Timur: PT. Intimedia Ciptanusantara.

Rachmawati, Dewi Oktofa. (2010). Penerapan model belajar self-directed learning untuk meningkatkan hasil belajar dan kemandirian belajar mahasiswa. Jurnal Pendidikan Dan Pengajaran Universitas Pendidikan Ganesha. 3, 177-183.

Rahmahwati, Fitria. (2013). Pengaruh sumber belajar, kemandirian belajar dan strategi pembelajaran terhadap hasil belajar ekonomi siswa SMA Negeri 8 Purworejo. Jurnal Oikonomia, 2, 49-54.

Sanan, Sabri Jamilah \& Yamin, H. Martinis. (2010). Panduan pendidikan anak usia dini. Jakarta: GP. Press.

Saputro, S.T., \& Pardiman. (2012). Pengaruh disiplin belajar dan lingkungan teman sebaya terhadap prestasi belajar mahasiswa program studi pendidikan akuntansi angkatan 2009 Fakultas Ekonomi Universitas Negeri Yogyakarta. Jurnal Pendidikan Akuntansi Indonesia, 1, 78- 97.

Suryabarata, S. (2002). Psikologi pendidikan. Jakarta: PT. Rajagrafindo Persada.

Syah, M. (2008). Psikologi pendidikan dengan pendekatan baru. Bandung: PT. Remaja Rosdakarya. 